\title{
Development Model Of School Management Based On Adiwiyata
}

\author{
Rizky Oktavian Saputra ${ }^{1}, \mathrm{Su} \mathrm{ad}^{2}$, Achmad Hilal Madjdi ${ }^{3}$ \\ \{rizkyoktaviansaputra@gmail.com ${ }^{1}$, suadfadlan@gmail.com², achmad.hilal@umk.ac.id ${ }^{3\}}$ \\ ${ }^{1,2,3}$ Faculty of Teaching and Education, Universitas Muria Kudus Gondang Manis PO. BOX 53 Bae, Kudus, \\ Central Java, Indonesia Phone (+62291) 438229, Fax (+62291)437198
}

\begin{abstract}
The purpose of this study was to obtain an overview of the school management Adiwiyata which has been implemented by the school Adiwiyata in Kudus and to develop model school management based Adiwiyata. The method used in this research is the Research and Development ( $R$ \& $\mathrm{D})$. whereas for data collection technique using informant interviews with relevant and direct observations. The development phase is carried out through: (1) the preliminary study, (2) modeling, (3) validation by experts from academia and practitioners, (4) the revision of product design and (5) a decent tested school management model. Data analysis is done through data reduction, data presentation, and conclusion that since before, during, and after the field. The results showed that the school management Adiwiyata no good planning and systematic, resulting Adiwiyata not maximized. Later it was found that during the implementation of the program Adiwiyata there has never been an evaluation or an evaluation program for the Adiwiyata school management. This research resulted in the product in the form of a school-based management model Adiwiyata equipped with a guide for those involved in the implementation of activities Adiwiyata. The model was developed following four components of management, including planning, organizing, implementing, and monitoring. Based on the due diligence carried out by experts and practitioners, the result that the model considered worthy to be tested by the practitioner.
\end{abstract}

Keywords: development, models, school management, Adiwiyata.

\section{Introduction}

In 2013 the growth of the world population has reached 7 billion, while the ecological footprint of the world population is not directly proportional to the availability of natural resources, energy, clean water, and food are dwindling. Imbalances reinforced by the data on which the world lost $50 \%$ of tropical forests, atmospheric $\mathrm{CO} 2$ concentration increased more than $25 \%$ are causing extreme climate change (US Bureau of the census, International Data Base 2011 Update).

Destruction and disregard for the environment is an issue that is inseparable from the modern life. Start of local environmental problems, such as waste disposal problems and the lack of green open space. Regional environmental problems such as industrial pollution and landslides. National environmental issues such as fishing with bombs and burning of forests, to the global environment such as global warming and the shrinking of the Poles wide. Such severe environmental damage, so the media spotlight and be the discussion seminars, research experts, observers, and environmental activists. Exploitation of natural resources is one of the factors triggering the occurrence of increasingly complex environmental problems. Of course, a variety of such damage does not escape the attention of the world of education. (Harris, et al, 
Damage to the environment becomes a serious problem faced by the countries in the world, including Indonesia. The rapid development and technological advances that ignore the environment has led to the increasing damage to the environment. It resulted in the loss of the ecological balance and environmental degradation as well as the reduction of groundwater discharge. Human activity is one of the elements that determine the quality of the environment. The amount of environmental damage are encouraging their efforts to implement environmental improvements.

Indonesia has become one of the countries that pay more attention to environmental management efforts. This is evidenced by the Act No. 32 of 2009 on the Protection and Environmental Management which is a systematic effort and integrated to preserve the function of the environment and prevent pollution or damage to the environment that includes the planning, utilization, control, maintenance, until the supervision of law enforcement.

Environmental issues related to the growing and diverse kinds, then the indispensable policy related to environmental management in order to reduce the rate of environmental degradation. National development is directed to apply concept of sustainable development or sustainable development (sustainable development). One element in the concept of sustainable development is environmental education in schools.

Further described by Hamzah (2013: 42-43) that environmental education is one effective way to prevent an environmental disaster. Environmental education carried out with reference to economic growth, social development and environmental protection.

According to Weiland and Morrison in Hamzah (2013: 62) will be able to develop the environmental education of students is more concerned about the environment if done continuously supported environmental education curriculum and infrastructure that support the environment in the educational process.

Adiwiyata interpreted as a good place and an ideal which can be obtained all the knowledge and norms and ethics that can be the basis for the creation of the welfare of human beings towards the ideals of sustainable development. As for the purpose of realizing the school community Adiwiyata is responsible for the protection and management of the environment through a good school governance to support sustainable development.

Adiwiyata program is expected to change the paradigm and behavior of school community. The growth of the human brain to reach perfection until the age of 20 years. At the age of humans still requires formal education to different levels. So at that age would be maximized in shaping the behavior of environmental care in meeting their needs.

From the above explanation, it can be concluded that a caring attitude towards the environment can be cultivated as early as possible with the implementation of Adiwiyata in school. Habituation, behavioral development, respect, love and care for the environment can become daily habits can occur with the integration of environmental education with the school program.

Some schools in Kudus ranging from elementary, junior high, or high school / vocational already implementing Adiwiyata and has been awarded both at district, provincial, national, and even self Adiwiyata. To get a clean city award, an area must have and develop Adiwiyata school. To be Adiwiyata School, a school must meet several prerequisites of carrying out four principal components and run the school-based management Adiwiyata.

Based on an initial interview to one of the team leaders Adiwiyata, it was found that the school management has not arranged neatly Adiwiyata, activities have not been programmed in detail, its implementation is still unclear although still carry habituation-conditioning loving environment. Further, he explained, it happens because of the difficulty in dividing time teaching load and divide tasks among teachers to be responsible for each activity. Moreover, 
there are several schools that kurng residents enthusiastic and committed to the running Adiwiyata, so that it becomes one of the challenges to realizing Adiwiyata good school management.

Preliminary study further shows that the effectiveness of school management Adiwiyata still low. This is especially true on a new Adiwiyata school or schools that would be Adiwiyata. In line with that submitted by one of the team leaders Adiwiyata, that there are no specific plans related to management activities. So that the activities carried out at the time Adiwiyata blank or customize with laiinya school activities and can not be thoroughly integrated with other school programs. Activities carried out was incidental only. In its organization also remains unclear division of duties and responsibilities, the composition of the team appears to be merely a formality because the executor of activity is usually just that's it.

A similar study conducted by Utami Dwi Ratna JuliaRi and colleagues in 2015 found the result that the status of national Adiwiyata school management is very good both policy and infrastructure, but not comparable to aspects of the curriculum and participatory aspects in good standing only. This is consistent with the findings of the team Adiwiyata district, where the two aspects of the improvement efforts are underway to establish partnerships with outside parties, active informant and improve the competence of teachers in developing local and global issues and to develop indicators of learning.

\section{Methodology}

This study was designed using a "research and development" or a "research and development". Which in this study, there are two activities, namely research, then from the results of these studies were developed in order to improve the program, a model or a product that already exists. To produce a product used in this study measures the development presented by Borg and Gall and developed by Sugiyono by level of study.

Procedures or stages in this developmental research follows the model of development by Borg and Gall. In addition to following the development model presented by Borg and Gall, this research also see the level of difficulty of research contained in the book Research Method Development by Sugiyono. In detail the development of research difficulty level is described as follows: (1) Research and development at level 1 (the lowest level) is a researcher conducting research to produce a draft, but did not proceed with making the product and testing it; (2) Research and development on level 2, is the researchers did not conduct research, but direct testing of existing products; (3) Research and development at Level 3, is a researcher conducting research to develop products that have been there, make the product and test the efficacy of the product; (4) Research and development at level 4, is a researcher conducting research to create new prouk make the product and test the effectiveness of these products (Sugiyono, 2019: 42).

But in the study of this development, given since developed is a model of school management which does not allow to implement all phases of development presented by Borg and Gall or can not be tested extensively and the limitations of time, money, school conditions and power, or in the case of this can be referred to develop the existing product was tested in a limited then through FGD (Sugiyono, 2019: 42)

The type of data collected in the study of this development is a form of qualitative data that contain the words, sentences, charts, drawings, photographs. The data was obtained from the documentation, field observation and informant interviews. Informants in this study is the whole school community is in direct contact in school activities, among other elements of 
leadership or principals as policy makers, teachers practice, students as subjects of the implementation of education and public schools as partners in carrying out the activities.

Data collection activities carried out at the stage of preliminary studies, where at this stage, an analysis of the needs or see the potential and problems existing in the field, gathering information and literature that is done through triangulation data obtained from structured interviews, structured observation and documentation. The data collection techniques will be explained as follows:

1. structured interview

According Sugiyono (2019: 214), structured waancara is done by providing questions to the informant with the same question.

2. structured observation

Structured observation is an observation that has been systematically designed, on what would be observed, when and where it is.

3. Documentation

Technical Documentation does is collecting data such as pictures, photographs, charts, and documents related to the research school.

In this study, using an instrument such as the questionnaires and observation sheets. These instruments are used in the three stages of research that is used for requirements analysis (know the potential and problems), used to identify products or models need to be developed and used to collect data in internal testing.

Data analysis technique used is a qualitative analysis is inductive, that is an analysis based on the data obtained, subsequently developed into a hypothesis, and then look for repetitive data to verify the hypothesis (Sugiyono, 2019: 368).

\section{Result and Discussion}

Based on the observations that have been made in some Adiwiyata schools and schools that are running towards Adiwiyata process, it was found that in Adiwiyata has not been implemented in a structured needs analysis. During the implementation of activities and new limited Adiwiyata spontaneous activity that has not been conceptualized and planned, so that the activities carried out only seem to meet the standard requirements, Adiwiyata, regardless of the usefulness and long-term goals as a school Adiwiyata.

Along with the lack of a needs analysisconducted by the school Adiwiyata, causing lack of formulation of a specific goal. During this purpose Adiwiyata activities are based on the program's main objectives Adiwiyata, which makes the school as a school Adiwiyata, without regard to principles of Adiwiyata itself. This is evidenced by the results of an interview with one of the teachers at the school Adiwiyata revealed "All I know is Adiwiyata clear program objectives to be Adiwiyata school where all citizens, especially school has a character loving environment. But for the specific purpose I had never know. If for special purpose I do not understand yes, it is the principal who knows, but what is clear is certainly the purpose of fostering is to help our school become a school Adiwiyata ". In Adiwiyata,

In Adiwiyata that have been run over the years, the material kegiatan determined spontaneously. There has been no determination of material created specifically activities based on the needs of the school. One Adiwiyata TIM Chairman said that in terms of material, made in langsungketika will carry out activities in accordance with the needs of the activities at the time and no material prepared in advance. This condition is one of the obstacles in Adiwiyata. 
When viewed from the side of the management functions of planning, so far there has been no planning activities are made carefully. During inipembinaan implementedIncidental thus preparing action plans as well as needed to be incidental only activity at the time. Things like this will affect the implementation and success of the program Adiwiyata.

In connection with the organization, as long as there is no formation of a special team to handle activities related to Adiwiyata. Conducted through observation and documentation study, found no board or committee structures in activities related to Adiwiyata.

In Adiwiyata, based on observation of Adiwiyata school located in Kudus, the higher level of recognition Adiwiyata by the school, the better the program implementation. But that did not participate showed that the implementation of school management is well defined Adiwiyata anyway. That's because most of the activities carried out only incidental as needed at the time. Only those that had a higher award, they have more experience so that it can carry out activities Adiwiyata better.

Related to the monitoring and evaluation of the program Adiwiyata, during Adiwiyata researchers visited schools in the Kabupaten Kudus, yet some schools conduct internal monitoring and evaluation to make a follow-up plan and perbaikna programs and activities in order to become better. They just rely on monitoring and evaluation of external parties or from the team coaches and assessors Adiwiyata District. Whereas evaluation is absolutely necessary to improve the quality of schools. These conditions resulted in the school can not measure the level of achievement, Adiwiyata implemented.

Based on the findings of the initial study, the sangatta requires the development of a school-based management model adiwiyat. Where this model will be used as a reference tool for the school to become a school Adiwiyata Adiwiyata really Adiwiyata and not just to meet program standards, but also follow the principle of good management and the principles of Adiwiyata itself.

\section{Conclusion}

In this study indicate that the environmental damage caused by humans already can not be stopped. Modern society that ignores many of the environmental preservation. This condition is exacerbated by the availability of natural resources that are no longer comparable with human needs. The situation has become a global problem.

The global problems can be minimized by providing environmental education to all levels of education. The Ministry of Education together with the Ministry of Environment in cooperation in initiating a caring school program and cultured environment called Adiwiyata.

Adiwiyata is an alternative solution to reduce environmental damage from an early age by teaching the children that the environment is very important for the sustainability of life on this earth. But Adiwiyata is not fully adhered to by schools Adiwiyata. Many schools only meet the standards without regard to principles Adiwiyata program.

Under these conditions, then it needs to be a model of school management which can be used as a reference to develop the school into a school Adiwiyata. Adiwiyata based school management model is an alternative solution for schools that want to become Adiwiyata schools, and schools Adiwiyata who wants to improve its management system to make it better.

\section{References}


Asmani, Jamal ma'mur. 2012. Tips Aplikasi Manajemen Sekolah. Yogyakarta: DIVA press.

Budiwibowo, Satrijo. 2018. Manajemen Pendidikan. Yogyakarta : Penerbit Andi.

Departemen Pendidikan dan Kebudayaan. 2003. Kamus Besar Bahasa Indonesia Edisi Kedua. Jakarta : Balai Pustaka

Departemen pendidikan nasional, paket pelatihan 1, peningkatan mutu pendidikan dasar melalui manajemen berbasis sekolah, peran serta masyarakat, pembelajaran aktif, kreatif, efektif dan menyenangkan, Juni 2005

Hamzah, Syukri. 2013. Pendidikan Lingkungan: Sekelumit Wawasan Pengantar. Bandung: Refika Aditama.

Haris, Endang. 2018. Sekolah Adiwiyata (Panduan Implementasi Adiwiyata Mandiri di Sekolah). Jakarta : Erlangga

Haryati, S. 2012. Research and Development (RnD) Sebagai Salah Satu Model Penelitian Dalam Bidang pendidikan. Vol. 37 No. 1, 15 September 2012 : 1126

http://blog.alimsumarno.com/perbedaan-penelitian-dan-pengembangan

Iskandar Wiryokusumo. 2011. Dasar-dasar Pengembangan Kurikulum. Jakarta: Bumi Aksara.

Karim, Abdul. 2018. Manajemen Lingkungan Hidup Berbasis Partisipasi. Pati : Kataba Group.

Kementerian Pendidikan dan Kebudayaan. 2013. Panduan Pembinaan Manajemen Berbasis Sekolah di Sekolah Dasar. Jakarta : Kemdikbud.

Kementrian Lingkungan Hidup Republik Indonesia. 2005. Pendidikan Lingkungan Hidup. http://www.menlh.go.id/pendidikan lingkungan hidup/. Diakses 11 Juni 2019

Majid, Abdul. 2005. Perencanaan Pembelajaran. Bandung : Remaja Rosdakarya.

Mochtar Noor Endah. Dkk. 2014. Pendidikan Untuk Pembangunan Berkelanjutan (Education for Sustainable Development) di Indonesia (Implementasi dan Kisah Sukses). Jakarta : Komisi Nasional Indonesua untuk UNESCO Kementerian dan Kebudayaan.

Mulyasa. 2017. Manajemen Berbasis Sekolah (Konsep, Syrategi, dan Implementasi). Bandung : Remaja Rosdakarya.

Muryanto. 2015. Manajemen Sekolah Adiwiyata di SD HJ. Isriati Moenadi Ungaran Kab. Semarang. Salatiga: MMP UKSW.

Permen Negara Lingkungan Hidup nomor 5 Tahun 2013 Panduan Adiwiyata 2012. Jakarta: KLH

Rosdiani, Dini. 2018. Manajemen Pendidikan. Bandung : Alfabeta.

Rusman. 2018. Manajemen Kurikulum. Depok : Raja Grafindo Persada.

Setyosari, Punaji. 2012. Metode Penelitian Pendidikan dan Pengembangan. Jakarta: Kencana Prenada Media Group.

Sudarwan Danim. 2007. Visi Baru Manajemen Sekolah (Dari Unit Birokrasi ke Lembaga Akademik. Jakarta: Bumi Aksara.

Sugiyono. 2006. Metode Penelitian Pendidikan. Bandung : Alfabeta

Sugiyono. 2019. Metode Penelitian \& Pengembangan. Bandung : Alfabeta

Suparman, A. 2014. Desain Instruksional Modern. Jakarta: Erlangga

Umaedi, dkk. 2015. Manajemen Berbasis Sekolah. Tangerang Selatan : Universitas Terbuka.

UNESCO, 2005a UNDESD

www.unescobkk.org/education/esd-unit/definition-of-esd 